\title{
The Effect of the Third Party Funds on People's Business Credit and Micro Business Segment Profitability
}

\author{
Nanang Saady, Theresia Pradiani, Yunus Handoko \\ Institute of Technology and Business Asia Malang \\ Email: saadynanang@gmail.com
}

\begin{abstract}
This study aims to reveal the direct effect of third-party funds (TPF) on People's Business Credit (PBC), Profitability, and the immediate effect of PBC on profitability, as well as the indirect effect of TPF on profitability through PBC. The study employs multiple linear regression data analysis through data processing using the Micro Business segment financial statements. The population and sample were the data of monthly TPF, Micro PBC, and profitability in the form of a Return on Assets (ROA) ratio from 2017 to 2019 period. The research target is the Micro Business segment in the Regional Office of PT. Bank Rakyat Indonesia (Persero) Tbk. (BRI) Malang. The results of the data analysis indicate that TPF has a direct effect on the increase of PBC and indirect impact on profitability, as well as an immediate effect of the increase $\mathrm{PBC}$ on the decrease of profitability.
\end{abstract}

Keywords: People's Business Credit, Third Party Funds, Return on Assets

\section{INTRODUCTION}

Banking is everything related to banks, covering institutions, business activities, as well as ways and processes in carrying out business activities. The bank represents a business corporation that collects public funds in the form of savings and distributes them to the public through credit or other arrangements to improve the living standard of people (Law No. 10 of 1998). A prominent element considered for granting credit to the public is third party funds (TPF) in stable conditions, TPF provides loans.

Third-Party Funds (TPF) are collected by banks from the public, consisting of deposits from Current Accounts, Savings Accounts, and Time Deposits. The increase in TPF can be allocated partly for credit delivery. The bank's income will increase from the interest earned and impact increasing bank Profitability (Kasmir, 2014). TPF is very important for the performance of banking operations. TPF is an element of revenue formation because the TPF is distributed in the form of financing or credit. The credit disbursed will get a rate of return in the form of interest. The size of the interest yield determines the level of profitability. Therefore optimization of TPF is vital in increasing profitability.

Bernadin and Sofyan (2019) proved that TPF is a significant contributor to banks in the process of channeling credit for the public so that the more excellent value of TPF, accelerates the bank's ability to disburse the loan. The primary revenue of banking is generated from credit distribution interest; a higher credit is channeled increases the interest income earned. The rise in income affects the profit amount (Kesuma, 2018). 
Fitri (2016) also stated theoretically and empirically that the TPF is proven to play a strategic role in Islamic financial institutions' performance. It supports several aspects such as certainty of management to provide financing or credit and influences business performance, especially in creating operational profit, which is crucial for the Islamic institution's business continuity. In contrast, Arumastuti and Sampurno (2016) mentioned that TPF has no significant effect on ROA. This situation is probably caused by imbalance credit channeled by banks with the funds gathered from the public so that a lot of funds settlers. The collected funds are not directed in the form of credit. Significant funds cannot significantly increase in ROA, as explained by Amelia and Murtiasih (2017). Therefore, the gaps found in the previous studies and occurring phenomena trigger the researchers to conduct this study.

Van Horne (2002) stated that Profitability ratios have two types of attractive benefits associated with sales, which show the relationship between profitability and investment. Both of these ratios show the efficiency of the company's operations. Weston and Brigham (2001) stated that Profitability ratios are a group of ratios that show the combined effects of liquidity, asset management, and debt on operating results. Three frequently used ratios are profit margin, return on asset (ROA), and return on equity (ROE). Koch and MacDonald (2003) argued that ROA is equal to net dividend income per total asset to measure the net profit of each asset owned during a specified period.

People's business credit (PBC) is credit or financing provided by banks to micro, small and medium enterprises (SMEs) which are feasible (businesses that are feasible to be given banking access), but not yet bankable (Coordinating Ministry for Economic Affairs, 2016). PBC is a credit program of the government, through channeling banks established by the government and is expected to increase the amount of credit given to the public. To guarantee against risks of loss, the government provides interest subsidy for entrepreneurs given directly to banks. The channeling bank allocated that interest subsidy, partly for the premium of credit insurance and partly as interest income.

Puspawati et al. (2016), in her findings, conveyed that there is a significant positive effect of TPF and Total Credit Distribution on Profitability. Credit distribution at profitability can weaken the company's size influence on Profitability (Parasthiwi and Budiasih, 2019). Dewi and Budiartha (2017) also reported that the level of credit channeling positively affects profitability, while TPF positively affects profitability.

In comparison with the results of a study conducted by Laila and PBCniawati (2018), which was then used as an empirical basis of this study, show the Regional Development Bank did not experience a significant difference of NPL and Profitability during before and after distribution of PBC. Rianawati and Taufik (2018) also stated that Third Party Funds (TPF) had a significant effect on the Bank's Profitability. The amount of credit extended has no considerable impact on the profitability of the bank. Previous research gaps and the existing phenomena strengthen the reasons that this research is essential.

Based on the explanation above, the purpose of this study is to find out: (1) whether TPF has a direct effect on TPF; (2) whether TPF has a direct impact on profitability; (3) does PBC affect profitability; (4) and whether TPF has an indirect 
effect on Profitability through PBC. The study was conducted at the BRI Regional Office Malang, focusing on the micro-business segment, which includes the amount of TPF, outstanding micro PBC, and the profitability of the micro-segment.

\section{METHODS}

The method used in this research was multiple linear regression analysis that measures the effect of more than one independent variable on the dependent variable. To determine the impact of the independent variables, Third Party Funds (TPF) and People's Business Credit (PBC) on Profitability, the following functions or models were used:

Where:

$$
\mathrm{Y}=\mathrm{a}+\mathrm{b} 1 \mathrm{X} 1+\mathrm{b} 2 \mathrm{X} 2+\mathrm{e}
$$

$$
\begin{aligned}
& \mathrm{Y}=\text { Profitability } \\
& \mathrm{a}=\text { Constant } \\
& \mathrm{b}=\text { Coefficient of the regression }
\end{aligned}
$$

$$
\begin{aligned}
& \mathrm{X} 1=\mathrm{TPF} \\
& \mathrm{X} 2=\mathrm{PBC} \\
& \mathrm{e}=\text { Error }
\end{aligned}
$$

In this study, the technical analysis used a part analysis regression technique (regression analysis of each part) in testing path analysis. Furthermore, the data analysis was carried out with the help of a computer using the SPSS program package version 23. The scope of the research in the banking sector focuses on several aspects, such as the micro-business segment at BRI Regional Office Malang, the independent variable TPF that affects the PBC distribution, and profitability, as a dependent variable.

The research location is in BRI Regional Office Malang, Laksamana Martadinata Street No. 80 Malang City, East Java. This place was chosen due to the micro-business segment. BRI Regional Office Malang has the highest TPF with the lowest cost of funds (Current Account Savings Account / CASA). The ratio of credit to TPF (Loan to Deposit Ratio/LDR) is the lowest compared to the rate of BRI's CASA and LDR. Also, it has the highest Return on Assets (ROA) ratio, outstanding PBC growth, and the most top outstanding micro-segment credit compared to the ROA, outstanding PBC ratio, and BRI's micro-segment credit. Moreover, it dominates the number of office outlets or equivalent offices with a micro-business segment (more than 10\%) compared to 19 other BRI Regional Offices. The research was carried out for four months from October 2019 to February 2020.

This study's population is the financial statements in the form of quantitative data of TPF, PBC, and Profit Ratio to the Asset (ROA) published by the Regional Office of BRI Malang monthly for three years, from January 2017 to December 2019. By using non-participant observation methods, the researchers were not involved and as free or independent observers.

The quantitative descriptive research was also carried out using data in the form of numbers or numbers calculated statistically, and then the researchers interpreted the analysis. The collected data were TPF, PBC, and Profitability (ROA). The data source was secondary data. The data were the documents retrieved from BRI Regional Office Malang in a period of three years, from January 2017 to 
December 2019. The following explains the relationship among variables as the discourse and the basis of this research.

\section{Third-Party Funds and People's Business Credit}

TPF has a significant and positive influence on the distribution of PBC. It happens because the source of funds used to distribute PBC is entirely derived from the PBC implementing bank. The largest source of funds owned by banks is obtained from Third Party Funds (TPF) sourced from public deposits in the form of current accounts, savings accounts, time deposits, and security deposits. The greater TPF collected by banks leads to more significant sources of funds (loanable funds) managed by banks. Consequently, there is an increase in the supply of funds to the public that has an impact on the higher number of credit distribution by banks (Rai and Purnawati, 2017).

Warjiyo (2004), stated that TPF is the largest source of funds owned and managed by banks to generate profits. Revenue from credit-giving services is credit interest, which is the most substantial income owned by banks. Thus, the higher number of third party funds owned by banks accelerates the amount of credit channeled to the public and bank profits.

\section{Third-Party Funds and Profitability}

$\mathrm{TPF}$ is a fund sourced from the public, an essential source for bank operational activities and is a benchmark of the success of a bank if the bank can cover the operating costs incurred in the office from this source of funds (Kasmir, 2014). If the deposits increase, the bank has more significant opportunities to obtain higher income. TPF is assumed to have a positive relationship with profitability. Besides, TPF does not have a substantial effect on ROA, because there is an imbalance between the credit channeled by banks and funds gathered from the public, causing a lot of funds to settle. Dewi and Budiartha (2017); Parasthiwi and Budiasih (2019); Rianawati and Taufik (2018) remarked that third-party funds had a positive impact on profitability.

In contrast, findings reported by Arumastuti and Sampurno (2016), stated that TPF is collected if they are not channeled in the form of credit or channeled into an investment. In other words, they are profitable for other activities that large funds cannot provide a significant increase in ROA.

\section{People's Business Credit (PBC) and Profitability}

Puspawati et al. (2016) mentioned a positive and significant correlation between the amount of credit distribution and profit. The placement in the form of credit will contribute to interest income that will impact Profitability (Dewi \& Budiartha, 2017), but Rianawati and Taufik (2018) remarked that the amount of credit delivered has no significant effect on profit. The banks' net profit annual acquisition is greatly influenced by crediting activities such as channeling by banks that will automatically reflect the bank's performance through the ratio of return on assets (ROA) (PBCniawati, 2012).

Based on the description of the model and conceptual framework and the results of previous studies, the researchers describe the framework of the research 
concept with the research model presented in Figure 1. Research Hypotheses, based on the conceptual framework, the following hypotheses are derived:

H1: Third Party Funds (TPF) directly affect People's Business Credit (PBC) microsegment in BRI Regional Office Malang.

H2: Third Party Funds (TPF) directly affect the profitability of micro-segment in BRI Regional Office Malang.

H3: Micro People's Business Credit (PBC) directly affect Profitability in BRI Regional Office Malang.

H4: Third Party Funds (TPF) indirectly affect Profitability through People's Business Credit (PBC).
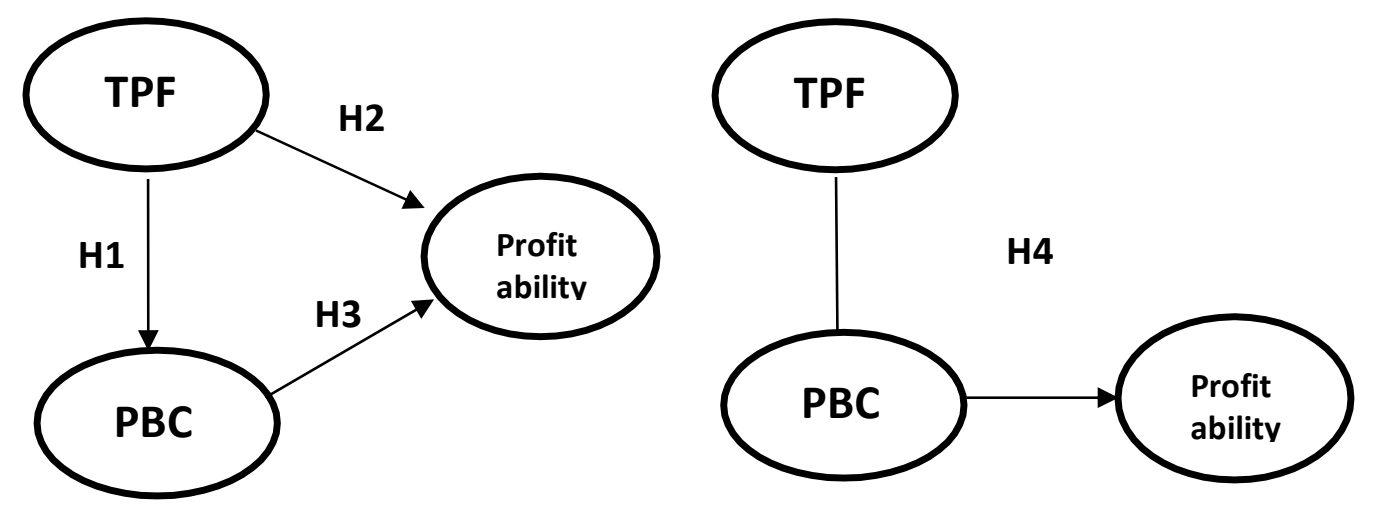

Figure 1. Conceptual Framework of the Research

The H1 hypothesis was derived from previous research (Bernadin and Sofyan, 2019; Puspawati et al., 2016), that suspect TPF has a significant effect on the distribution of PBC at the BRI Regional Office Malang. The H2 hypothesis was derived from research (Amelia and Murtiasih, 2017; Arumastuti and Sampurno, 2016), which states that the TPF has no significant effect on Profitability in the BRI Regional Office Malang. However, Parenrengi and Hendratni (2018) and Rianawati and Taufik (2018) suspected that the TPF had a significant effect on profitability at the BRI Regional Office Malang.

The H3 hypothesis was derived from the research conducted by Rianawati and Taufik (2018), along with Laila and PBCniawati (2018). They suspect that PBC distribution does not have a significant effect on profitability at the BRI Regional Office Malang, while Parenrengi and Hendratni (2018) and Parasthiwi and Budiasih (2019) suspect PBC distribution has a significant effect on Profitability at BRI Regional Office Malang.

\section{RESULTS \& DISCUSSION}

This study aims to find out whether TPF has a direct effect on PBC, whether TPF has a direct effect on profitability, does PBC affect profitability, and whether TPF has an indirect effect on profitability through PBC. After analyzing the data based on the research method described, the findings are explored as follows: 


\section{Direct Effect TPF on PBC}

TPF has a direct effect on PBC, as described with a beta coefficient of 0.776 with a significance level of 0.00 , due to the significance level of the analysis result is smaller than alpha 0.05. Based on the analysis of the relationship path I exposed in Figure 2, it is known that b1, which is the coefficient of direct influence between TPF to PBC, is described with a beta coefficient of 0.776 with a significance level of 0.000 . Because the significance level of the analysis is smaller than alpha 0.05 , it can be concluded that there is a significant direct effect between TPF against PBC in a positive direction (because the path coefficient is positive). In statistical language, it means the higher TPF, then PBC will be higher. Similarly, due to the lower TPF, the PBC will also be lower.

Furthermore, the value of the coefficient of determination (R Square) shows the amount of 0.603 , representing the magnitude of influence of the TPF against PBC. This means that $60.3 \%$ of PBC diversity is influenced by the TPF factor, While other factors outside the observed variables determined the remaining 39.7 percent. The residual coefficient of TPF's direct influence on $\mathrm{PBC}$, with the symbol e1, for the relationship path I is calculated using the following formula.

$$
\mathrm{e} 1=\sqrt{ }\left(1-\mathrm{R}^{2}\right)=\sqrt{ }(1-0.602)=0.630
$$

Thus from Table 1, we get the second equation model using the following formula:

$$
\begin{gathered}
\mathrm{PBC}=\mathrm{b} 1 \mathrm{X} 1(\mathrm{TPF})+\mathrm{e} 1 \\
\mathrm{PBC}=0.776 \mathrm{X}_{1}(\mathrm{TPF})+0.630
\end{gathered}
$$

Table 1. The result of direct impact analysis on PBC

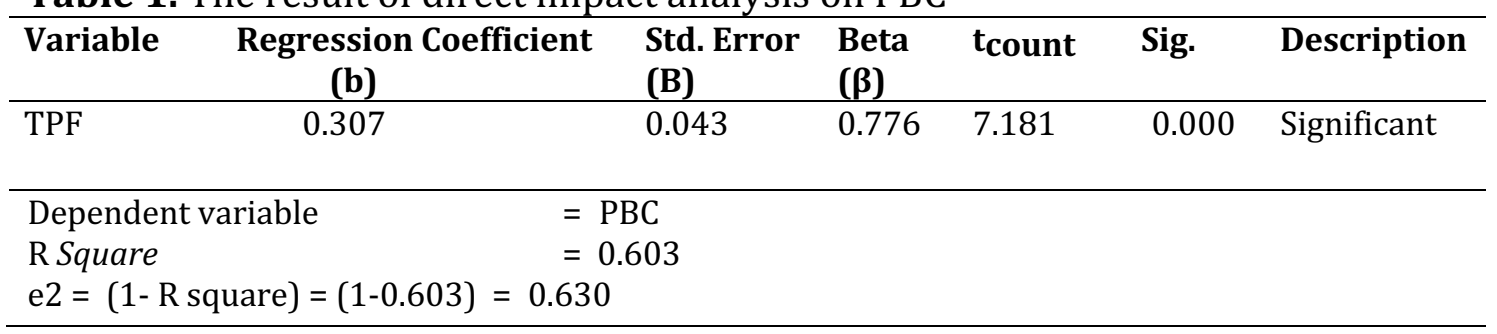

If the coefficient of direct influence between variables on the relationship path I is included in the model, then the model image of the immediate effect of relationship I appear in Figure 5.4. Based on the results of the analysis of the relationship path I, it can be concluded that: H1: Third Party Funds (TPF) directly affect People's Business Credit (PBC) micro-segment in BRI Regional Office Malang.

From the results of the path analysis, TPF has a significant effect on the PBC micro-segment at BRI Regional Office Malang. This is illustrated by a beta coefficient of 0.776 , with a significance level of 0.000 . The results of this study support the research conducted by Bernadin and Sofyan (2019) and Puspawati et al. (2016). The results of their studies reported that TPF has a significant effect on the distribution of PBC. 


\section{Direct Effect from PBC and TPF to Profitability}

The hypothesis proposed in this study is the existence of a direct influence from PBC and TPF to Profitability.
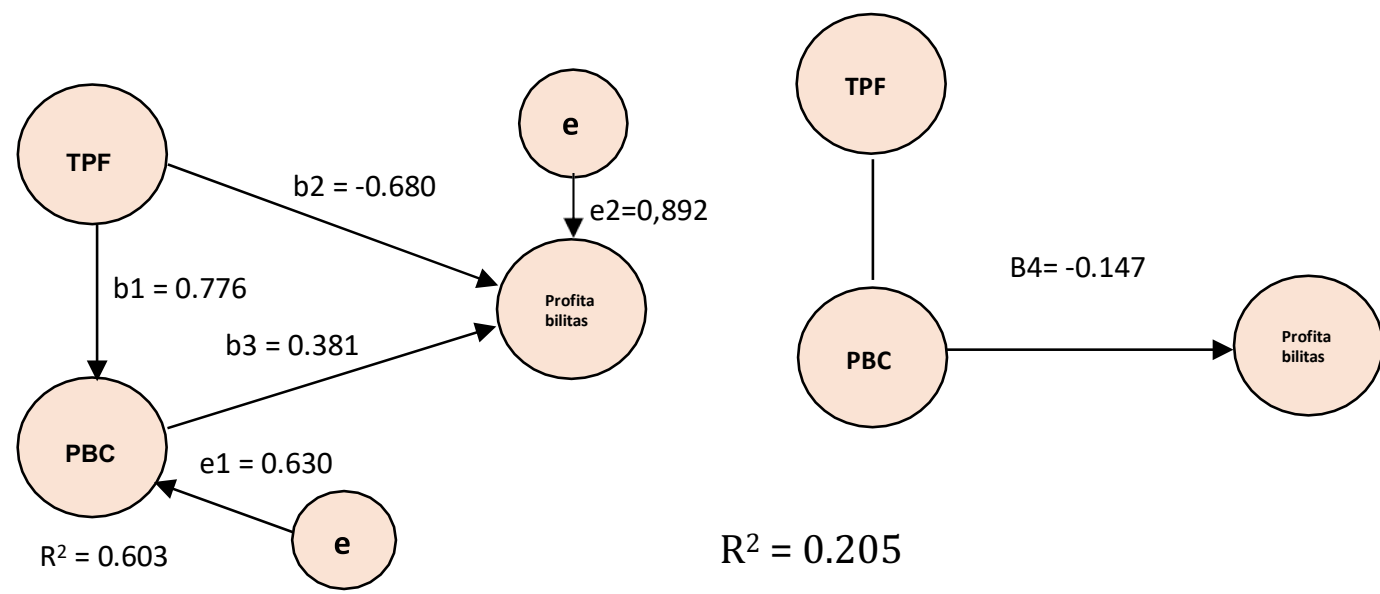

Figure 2. Path Analysis Result

Based on a theoretical study and sorting relationship path II, the hypotheses of this study are:

H2: Third Party Funds (TPF) directly affect the profitability of micro-segment in BRI Regional Office Malang.

H3: Micro People's Business Credit (PBC) directly affect Profitability in BRI Regional

Office Malang.

It is known that b2 is the coefficient of direct influence between PBC and Profitability, described by the beta coefficient of -0.680 with a significance level of 0.009. Because the significance level of the analysis results is smaller than alpha 0.05 , it can be concluded that there is a significant direct effect between PBC on Profitability, with a negative direction (because the path coefficient is negative). It means that the higher the $\mathrm{PBC}$, the lower profitability will be, whereas the lower PBC, the higher the profitability will be.

The coefficient of direct effect between TPF on Profitabiltas is illustrated by the beta coefficient (b3) of 0.381 , with a significance level of 0.131 . Because the significance level of the analysis results is more significant than alpha 0.05 , it can be concluded that there is no significant direct effect between TPF on Profitability. It means that high or low TPF does not affect high or low profitability.

Meanwhile, the coefficient of determination (R Square $=\mathrm{R} 2$ ) shows 0.205, which states the amount of the influence of PBC and TPF on Profitability. It means that $20.5 \%$ of the diversity of profitability is influenced by the existence of PBC and TPF factors. While the remaining $79.5 \%$ is determined by other factors outside the variables studied.

The residual coefficient of PBC and TPF direct influence on profitability, with the symbol e2, for the relationship path II is calculated by the formula:

$$
\mathrm{e} 2=\sqrt{ }\left(1-\mathrm{R}^{2}\right)=\sqrt{ }(1-0.205)=0.892
$$

Thus from Table 2, the following first equation model is obtained: 


$$
\begin{gathered}
\text { Profitability }=b_{2} \mathrm{X}_{1(\mathrm{PBC})}+\mathrm{b}_{3} \mathrm{X}_{2}(\mathrm{TPF})+\mathrm{e}_{2} \text { Profitability }=-0.680 \mathrm{X}_{1(\mathrm{PBC})}+0.381 \mathrm{X}_{2} \\
(\mathrm{TPF}) \\
+0.892
\end{gathered}
$$

If the coefficient of direct influence between variables on the relationship path II is included in the model, then the image of the direct relationship II appears in Figure 2. From the results of the analysis of the relationship path II based on the hypothesis stated, it can be concluded as follows:

H2: Third Party Funds (TPF) directly affect the profitability of micro-segment in BRI Regional Office Malang.

H3: Micro People's Business Credit (PBC) directly affect Profitability in BRI Regional Office Malang.

The results of the analysis found that there was no significant direct effect between TPF on Profitability. The coefficient of direct influence between TPF on Profitability was illustrated with a beta coefficient (b3) of 0.381 , a significance level of 0.131 . Therefore the significance level of the analysis results is more considerable than alpha 0.05. The results of this research are supported by Amelia and Murtiasih (2017) and Arumastuti, and Sampurno (2016), who mentioned that TPF had no significant effect on profitability. Additionally, this research did not support the research findings of Parenrengi and Hendratni (2018) and Rianawati, and Taufik (2018), who revealed that TPF had a significant effect on profitability.

The analysis results found that Micro PBC significantly influences the profitability of the micro-segment in BRI Regional Office Malang. It is verified by a beta coefficient of -0.680 , a significance level of 0.009 , where the higher the PBC, the lower the profitability will be, whereas the lower PBC, the higher profitability will be. The results of this research do not support the research conducted by Laila and PBCniawati (2018) and Rianawati and Taufik (2018), who suspect that the distribution of PBC has no significant effect on Profitability in the BRI Regional Office Malang. However, the results of this research support the research conducted by Parasthiwi and Budiasih (2019), and Parenrengi and Hendratni (2018), that suspect People's Business Credit Distribution (PBC) has a significant effect on profitability.

\section{Indirect Effect of TPF on Profitability through PBC}

After knowing the direct effect of each independent variable, TPF, and PBC, on the dependent variable profitability for both the first and second regression equation models, the indirect effect of the TPF on Profitability through PBC is calculated.

It is necessary to construct a track model in the path analysis in Figure 2 to make it easier to interpret the findings. The results of this path analysis can be concluded based on hypothesis $\mathrm{H} 4$, which mentioned that:

H4: Third Party Funds (TPF) indirectly affect Profitability through People's Business Credit (PBC).

From the results of path analysis, it can be said that there is no significant direct effect between TPF on profitability. Empirically, it was proven along with the description of the statistical results above. Meanwhile, descriptively, it can be seen 
from the real condition at BRI Regional Office Malang that the increase of the amount of Third Party Funds consisting of Current Account, Savings Accounts, and Time Deposits did not have a direct and significant effect on the rise in Profitability, TPF, and financing volume. It because the increase in profitability by $20.5 \%$ diversity of profitability was influenced by the existence of PBC and TPF factors. While the remaining 79.5 percent is determined by other factors outside the variables studied, this is quite interesting, so that further research needs to be done.

TPF is the primary source of bank funds in providing credit, including PBC. Thus, the increase of TPF makes banks more flexible to improve the distribution of funding to the public for additional capital for their business activities. However, there are some provisions in the banking system relating to the collecting TPF and giving credit that not all TPF that successfully compiled can be channeled in the provision of credit. The Financial Services Authority and Bank Indonesia, as the regulator, regulate banks to store TPF at Bank Indonesia in a certain percentage of the Minimum Statutory Reserves Account (GWM). Bank Indonesia provides interest on deposits of TPF in the Statutory Reserves, but the interest rates rate are low, and GWM interest income received by the banks is very small.

If the TPF is channeled back to the community in the form of credit, such as PBC, the bank will receive higher interest income than the GWM. The PBC interest rate is 7 percent per year, while the GWM interest is 5.5 percent per year.

Interestingly, the results show that there is a significant direct effect between TPF on PBC, with a coefficient of 0.776. Therefore, it can be explained that the increase in Third Party Funds in the form of current accounts, savings accounts, and time deposits can increase PBC at BRI Regional Office Malang. This discovery is a positive finding that needs to be examined in depth to help establish banking management strategies.

For the advancement of the management of BRI Regional Office Malang, the strategies in using TPF for PBC should be developed by arranging the composition of CASA (Current Account Saving Account) in Third Party Funds and optimizing the structure of Micro PBC (low-interest loans) in the overall outstanding microcredit. Therefore, the income composition of credit would be higher. From the path analysis, it is found that there was a significant direct effect between PBC on Profitability but negative, with a coefficient of -0.680 , meaning that an increase in outstanding $\mathrm{PBC}$ had an effect on decreasing profitability. Meanwhile, when outstanding $\mathrm{PBC}$ declined, the impact on profitability rose. If it is examined more deeply, it means that if the amount of PBC increases, but not balanced with the timeliness of the loan repayment that has been set by the bank, it is very influential in decreasing the bank Profitability. High PBC outstanding, but the small return on assets, will affect bank Profitability.

Another result of this study is, there is an indirect effect between TPF on Profitabiltas through $\mathrm{PBC}$ of -0.528 , meaning that $\mathrm{PBC}$ can reduce the influence of TPF on Profitability so that TPF has total influence on the profitability of -0.147 , which is relatively weak. Back to the previous explanation above, even an increase in TPF will cause the volume of the cost to increase, the number of PBC increases but the return on assets is small, it will affect the profitability of the bank, this needs to be watched out by BRI Regional Office Malang. 
Table 2. The Result of Direct Impact Analysis of PBC and TPF on Profitability

\begin{tabular}{|c|c|c|c|c|c|c|}
\hline Var & $\begin{array}{c}\text { Regression } \\
\text { coefficient (b) }\end{array}$ & Std. Error (B) & Beta $(\beta)$ & $t$ count & Sig. & Description \\
\hline $\mathrm{PBC}$ & -0.0000004610 & 0.0000001669 & -0.680 & -2.762 & 0.009 & Significant \\
\hline TPF & 0.0000001023 & 0.0000000661 & 0.381 & 1.547 & 0.131 & insignificant \\
\hline \multicolumn{2}{|c|}{$\begin{array}{l}\text { Dependent } \\
\text { variable }\end{array}$} & \multicolumn{5}{|l|}{$\begin{array}{l}=\text { Profitability } \\
=0.205\end{array}$} \\
\hline
\end{tabular}

The indirect effect of the independent variables, TPF and PBC, on the dependent variable, profitability, can be determined through the multiplication of the direct effect value (standardized beta coefficient) on each equation. Based on the results of the path analysis that has been completed, the table of the direct and indirect effects of TPF and PBC on Profitability can be drawn up, as presented in Table 2, along with manual calculations for the Indirect Effect of TPF on Profitability through PBC.

\section{CONCLUSION}

Based on the testing using predetermined methods, for the micro-business segment at BRI Regional Office Malang, the following conclusions are obtained. First, the increase in Third Party Funds (TPF) has a direct effect on increasing outstanding People's Business Credit (PBC). Second, the increase in TPF does not directly influence the increase in profitability. Third, the increase in outstanding PBC has a direct effect on decreasing profitability. Fourth, the increase in TPF does not directly influence the increase in profitability even though through PBC. The micro-business segment in the BRI Regional Office Malang is recommended to consider several factors. First, an increase in the amount of TPF collection must be channeled back to the community in the form of Micro PBC. Second, the TPF that has not been channeled in the form of credit (Micro PBC and other Micro Credits) is sold to the money market through the BRI Head Office. Even though the interest of the money market is lower than the PBC interest rate and other Micro Credits, it still generates a higher interest income than the interest expense paid to owners of current accounts, savings accounts, and time deposits. Third, an increase in Micro PBC has a direct effect on reducing profitability, but with the strategy of managing the outstanding PBC composition with other Micro Credits such as Kupedes and Briguna, which interest rates are higher than PBC, will optimally increase the acceptance of the interest in total and will increase profitability. Besides that, potential PBC customers are embryos as Kupedes prospective customers, so that when PBC customer businesses get bigger and require more significant credit from the PBC ceiling, they can become Kupedes customers. For futher research is expected yo develop this theme into educational aspects. 


\section{REFERENCES}

Amelia, K. C., \& Murtiasih, S. (2017). Analisis pengaruh TPF, LDR, NPL dan CAR terhadap jumlah penyaluran kredit pada PT. Bank QnB Indonesia, Tbk Periode 2005 - 2014. Jurnal Ekonomi Bisnis, 22(1), 66-74.

Arumastuti, N. K., \& Sampurno, D. (2016). Analisis pngaruh CAR, NIM, LDR, biaya operasi, size dan TPF terhadap ROA (Studi kasus pada bank umum konvensional yang terdaftar di BEI periode 2010-2014) (Unpublished undergraduate's Thesis). Fakultas Ekonomika dan Bisnis Universitas Diponegoro, Semarang.

Bernardin, D. E. Y., \& Sofyan, I. (2019). Penyaluran kredit dengan eksistensi dana pihak ketiga. Jesya (Jurnal Ekonomi \& Ekonomi Syariah), 2(1), 126-135.

Dewi, N. P. E. N., \& Budiasih, I. G. A. N. (2016). Kualitas kredit sebagai pemoderasi pengaruh tingkat penyaluran kredit dan BOPO pada profitabilitas. E-Jurnal Akuntansi Universitas Udayana, 15(1), 784-798.

Fitri, M. (2016). Peran dana pihak ketiga dalam kinerja lembaga pembiayaan syariah dan faktor-faktor yang memengaruhinya. Economica: Jurnal Ekonomi Islam, 7(1), 73-95.

Kasmir, (2014). Dasar-dasar perbankan. PT. Raja Grafindo Persada, Jakarta.

Kesuma, M. (2018). Pengaruh perubahan NPL (non performing loan) terhadap penyaluran kredit pada PT Bank Sumut Cabang Stabat. Jurnal Riset Akuntansi \& Bisnis, 18(1), 27-38.

Koch, T. W., \& MacDonald, S. S. (2003). Bank Management, $6^{\text {th }}$ ed. Thomson Learning, USA.

Kurniawati, A. (2012). Pengaruh penyaluran kredit dan tingkat suku bunga terhadap profitabilitas (ROA) (studi kasus pada perusahaan sektor perbankan yang terdaftar di bursa efek indonesia periode 2008-2012). E-Lib Unikom.

Laila, N., \& Kurniawati, E. P. (2018). Penyaluran kredit usaha rakyat bagi kinerja bank pembangunan daerah. Jurnal Ekonomi dan Bisnis, 21, 23-42. https://doi.org/10.24914/jeb.v21i1.633

Parasthiwi, T. D., \& Budiasih, I. G. A. N. (2019). Pengaruh kecukupan modal, penyaluran kredit dan ukuran perusahaan pada profitabilitas dengan risiko kredit sebagai pemoderasi. E-Jurnal Akuntansi, 791. https://doi.org/10.24843/EJA.2019.v26.i01.p29

Parenrengi, S., \& Hendratni, T. W. (2018). Pengaruh dana pihak ketiga, kecukupan modal dan penyaluran kredit terhadap profitabilitas bank. Jurnal Manajemen Strategi dan Aplikasi Bisnis, 1(1), 9-18.

Puspawati, L., Cipta, W., \& Yulianthini, N. N. (2016). Pengaruh dana pihak ketiga dan jumlah penyaluran kredit terhadap laba. Jurnal Manajemen Indonesia, 4(1), $1-10$.

Rai, I. A. A., \& Purnawati, N. K., 2017. Faktor - faktor yang mempengaruhi kredit pada bank umum swasta nasional (BUSN) devisa. E-Jurnal Manajemen Unud 6(11), 29. 
Rianawati, D., \& Taufik, N. I. (2018). Pengaruh dana pihak ketiga, kredit yang disalurkan dan kredit non lancar terhadap laba (the impact of third parties funds, distributedloans on profitabilites)(studi kasus pada bank nusantara parahyangan cabang sudirman). Jurnal Akuntansi, 10(1), 17-29.

Undang-undang RI Nomor 10, 1998. Undang-undang RI Nomor 10 Tahun 1998.

Van Horne, J. C. (2002). Financial management and policy. Prentice Hall International Inc, USA.

Warjiyo, P. (2004). Mekanisme transmisi kebijakan moneter di Indonesia. Pusat Pendidikan dan Studi Kebanksentralan BI, Jakarta.

Weston, J. F., \& Brigham, E. F. (1990). Dasar-dasar manajemen keuangan Jilid 2. Jakarta: Erlangga. 